\title{
The Pawpaw Regional Variety Trial: Background and Early Data
}

\author{
Kirk W. Pomper, ${ }^{1}$ Desmond R. Layne, ${ }^{2}$ R. Neal Peterson, ${ }^{3}$ and Dwight Wolfe ${ }^{4}$
}

AdDITIONAL INDEX WORdS. Asimina triloba, kentucky banana

Summary. Beginning in 1993, 12 institutions and individuals and The PawPaw Foundation (PPF) embarked on a joint venture to evaluate commercially-available, named pawpaw (Asimina triloba) varieties and PPF's advanced selections within and outside of the pawpaw's native range. Each Pawpaw Regional Variety Trial (PRVT) planting, consists of about 300 trees, with five to eight replications (blocks) of 28 grafted scion varieties per block in a randomized complete block design (10 named varieties and 18 clones selected in the PPF orchards at the University of Maryland Experiment Stations at Queenstown and Keedysville, Md.). Variables being examined in the trial include climatic effect, culture, pests, growth, flowering, yield, and fruit characteristics. In 1995, PRVT plantings were established in Kentucky (Princeton, Ky.), Louisiana, North Carolina, Oregon, and South Carolina. In 1998, a second planting was established in Kentucky (Frankfort, Ky.). In 1999, PRVT plantings were established in Indiana, Iowa, Michigan, Maryland, Nebraska, New York, and Ohio. In the Frankfort planting, 95\% of the trees have survived. Based on height and trunk diameter measurements taken from 1998 to 2001 , most selections displayed good vigor. The variety PA-Golden had the best early fruit production as evidenced by the fact that five of eight trees had fruit in 2001. In the Princeton, planting, only 54\% of the trees have survived. The selections 'Sunflower', 'PA-Golden', 'NC-1', 'Wilson', 1-23, 8-20, and 9-58 showed the best fruit production and survival rates $(>63 \%)$ in 2001 . Based on limited data collected so far in the Kentucky trials, 'PA-Golden' and 'Sunflower' have performed well in the two locations and other varieties and PPF selections show promise.

$\mathbf{T}$

he pawpaw tree produces the largest edible fruit native to the United States (Darrow, 1975; Layne, 1996). Pawpaws are hardy to USDA growing zone 5

$\left[-26.1{ }^{\circ} \mathrm{C}\left(-15^{\circ} \mathrm{F}\right)\right]$ and grow wild in the mesic hardwood forests of 26 states in the eastern United States, ranging from northern Florida to southern Ontario (Canada) and as far west as eastern Nebraska (Kral 1960). In the wild, pawpaw trees grow 5 to $10 \mathrm{~m}$ (16.4 to $32.8 \mathrm{ft})$ tall, and are usually found in the forest understory in the deep, rich fertile soils of river-bottom lands (Lagrange and Tramer, 1985; Sargent, 1890). In sunny locations, trees typically assume a more compact pyramidal growth habit, with a straight trunk and long, drooping leaves. Dark maroon blossoms occur singly on the previous year's wood, emerging before leaves in midspring. Flowers have a globular androecium and a gynoecium usually composed of three to seven carpels or three to sevenfruited clusters (Kral, 1960); up to nine-fruited clusters have been noted in the Kentucky State University (KSU) orchards (unpublished).

This research was supported by U.S. Dept. of Agriculture, Cooperative State Research, Education, and Extension Service Agreement no. KYX-10-97-28P with Kentucky State University. The technical assistance of S. Jones and E. Reed is also gratefully acknowledged by the authors. We wish to thank G. Brown for his assistance in propagating trees and establishing the planting in Princeton, Ky.

${ }^{1}$ Principal investigator of horticulture and curator, USDA National Clonal Germplasm Repository for Asimina species., Atwood Research Facility, Kentucky State University, Frankfort, KY 40601-2355. To whom reprint requests should be addressed.

${ }^{2}$ Associate professor of pomology and extension fruit specialist, Dept. of Horticulture, Box 340375, Clemson Univ., Clemson, SC 29634-0375.

${ }^{3}$ Peterson Pawpaws, P.O. Box 1011, Harpers Ferry, WV 25425.

${ }^{4}$ Horticulture research specialist, Department of Horticulture, University of Kentucky, Research \& Education Center, P.O. Box 469, 205 Hopkinsville Street, Princeton, KY 42445 
Flowers are strongly protogynous and are likely self-incompatible (Willson and Schemske, 1980), although some trees may be self-compatible. Pollination may be by flies (Diptera) (Willson and Schemske, 1980) and beetles (Nitidulidae) (Kral, 1960). Fruit set in the wild is usually low and may be pollinator or resource-limited (Lagrange and Tramer, 1985; Willson and Schemske, 1980), but under cultivation in full sun, tremendous fruit loads have been observed. Fruit may be borne singly or in clusters, which resemble the hands on a banana plant (Musa spp.). When ripe, the fruit softens and has a powerful aroma (McGrath and Karahadian, 1994; Shiota, 1991). In some varieties, there is a skin color change from green to green-yellow (e.g., 'PA-Golden \#l' and ' $10-35$ ') when the fruit ripens. Flesh color of ripe fruit ranges from creamy white through bright yellow to shades of orange. The flavor of ripe pawpaw fruit resembles a combination ofbanana (Musa xparadisiaca), mango (Mangifera indica), and pineapple (Ananas comosus); however, flavor varies among varieties, with some fruit displaying more complex flavor profiles. Usually the shelf life of a tree-ripened fruit stored at room temperature is 2 to $3 \mathrm{~d}$, but with refrigeration $\left[4^{\circ} \mathrm{C}(39.2\right.$ $\left.{ }^{\circ} \mathrm{F}\right)$ ], fruit can be held at least 3 weeks while maintaining good eating quality. As early as 1916 it was noted that the rapid perishability of pawpaw fruit was the major factor inhibiting its commercialization, but that this problem might be solved through breeding efforts (Popenoe, 1916, 1917). Whether there is significant variation in keeping ability of fruit in wild pawpaw germplasm has yet to be determined.

Efforts to domesticate the pawpaw began early in the $20^{\text {th }}$ century (Peterson, 1991; Zimmerman, 1941). Pawpaw selections from the wild were assembled in extensive collections by various enthusiasts and scientists, including Benjamin Buckman (Farmington Ill., circa 1900 to 1920), George Zimmerman (Linglestown, Pa., 1918 to 1941), and Orland White (Blandy Experimental Farm, Boyce, Va., 1926 to 1955 ) (Peterson, 1986; Peterson 1991; Zimmerman, 1941). From about 1900 to 1960 , at least 56 varieties of pawpaw were selected and named. Fewer than 20 of these selections remain, with many being lost from cultivation through neglect, abandonment of collections, and loss of records necessary for iden- tification (Peterson, 1991). With the resurgence of interest in pawpaw since 1960, additional pawpaw varieties have been selected in the wild or as a result of breeding efforts of hobbyists. There are currently more than 40 pawpaw varieties commercially available (Jones et al., 1998). In 1994, KSU was approved as the USDA National Clonal Germplasm Repository, or gene bank, for Asimina species. Therefore, germplasm evaluation, preservation, and dissemination have been a high priority for the KSU program since that time. There are presently over 1700 accessions from 17 states and over 40 varieties contained in the repository orchards. Several isozyme and DNA marker techniques have been used to evaluate genetic diversity of pawpaw varieties and material collected from wild populations in the KSU repository collection, and also to fingerprint varieties to establish a baseline for future variety authentication and breeding efforts (Huang et al., 1997, 1998, 2000, 2002; Pomper et al., 2003).

In 1981, R. Neal Peterson and Harry Swartz began a long-term breeding project which aimed to develop improved pawpaw varieties (Peterson 1986, 1991). A collection of about 1500 accessions of open-pollinated seedlings was assembled at the University of Maryland Experiment Stations at Queenstown and Keedysville, Md. The seed for this gemplasm collection was obtained from pawpaw trees that remained at the sites of the historic collections of Buckman, Zimmerman, the Blandy Experimental Farm, as well as those of Hershey (Dowington, Pa.), Allard(Arlington, Va.), Ray Schlaanstine

Table 1. Genetic background of pawpaw selections ${ }^{z}$ included in the Kentucky Pawpaw Regional Variety Trials (PRVT).

\begin{tabular}{ll}
\hline Clone & Genetic background \\
\hline $1-7-1$ & Open-pollinated seedling of 'Overleese' \\
$1-7-2$ & Open-pollinated seeding from BEF-30' \\
$1-23$ & Open-pollinated seedling of 'Taylor' \\
$1-68$ & Open-pollinated seedling from 'Overleese' \\
$2-10$ & Open-pollinated seedling of BEF-30 \\
$2-54$ & Open-pollinated seedling of GAZ-VA' \\
$3-11$ & Open-pollinated seedling of BEF-33 \\
$3-21$ & Open-pollinated seedling of BEF-43 \\
$4-2$ & Open-pollinated seedling of BEF-53 \\
$5-5$ & Open-pollinated seedling of BEF-54 \\
$7-90$ & Open-pollinated seedling of RS-2w \\
$8-20$ & Open-pollinated seedlings of 'Sunflower' \\
$8-58$ & Open-pollinated seedling of BEF-30 \\
$9-47$ & Open-pollinated seedling of BEF-49 \\
$9-58$ & Open-pollinated seedling of BEF-50 \\
$10-35$ & Open-pollinated seedling of BEF-49 \\
$11-5$ & Open-pollinated seedling of BEF-53 \\
$11-13$ & Open-pollinated seedling of BEF-53 \\
'Middletown' & Wild seedling from Middletown, Ohio \\
'Mitchell' & Wild seedling from Iuka, Ill. \\
'NC-1' & 'Davis' female $\times$ 'Overleese' male \\
'Overleese' & Cultivated (open-pollinated) seedling from Rushville, Ind. \\
'PA-Golden' & Second-generation seedling from G.A. Zimmerman collection \\
'Sunflower' & Wild seedling from Chanute, Kans. \\
'Taylor' & Wild seedling from Eaton Rapids, Mich. \\
'Taytwo' & Wild seedling from Eaton Rapids, Mich. \\
'Wells' & Cultivated (open-pollinated) seedlings from Salem, Ind. \\
'Wilson' & Wild seedling from Cumberland, Ky. \\
\hline
\end{tabular}

${ }^{2}$ Numbered selections from the PawPaw Foundation orchards; numerous wild selections from the remnant collections of H.A. Allard (Arlington, Va.), Blandy Experimental Farm (Boyce, Va.), B. Buckman (Farmington, Ill.), J. Hershey (Dowington, Pa.), R. Schlaanstine (West Chester, Pa.), and G. Zimmerman (Linglestown, Pa.), plus some from truly wild trees and some from named varieties that were assembled by R. N. Peterson and H.J. Swartz at the Univ. of Maryland Experiment Stations in Keedysville and Queenstown, Md.

'BEF = Blandy Experimental Farm collection (Boyce, Va.); numerous wild seedlings plus portions of Zimmerman's collection, donated posthumously; assembled by Orland E. White and staff at Boyce, Va., from 1926 to 1955 ${ }^{\mathrm{x}} \mathrm{GAZ}=$ George A. Zimmerman collection containing most, if not all of the named varieties of the time plus numerous wild selections and interspecific hybrids; assembled by George A. Zimmerman of Linglestown, Pa., from 1920 to 1940 .

"RS = Ray Schlaanstine collection, material descending from Zimmerman's collection via John Hershey; assembled by Ray Schlaanstine of West Chester, Pa., date uncertain, $\approx 1960$. 
Table 2. Pawpaw Regional Variety Trial (PRVT) cooperators and cooperating institutions by location.

\begin{tabular}{|c|c|c|c|}
\hline State & Cooperator & Institution & Location \\
\hline Iowa & Patrick O'Malley and Tom Wahl & Iowa State Univ. & Crawfordsville, Iowa \\
\hline Kentucky & Kirk Pomper & Kentucky State Univ. & Frankfort, Ky. \\
\hline Kentucky & Joseph Masabni/Dwight Wolfe & Univ. of Kentucky & Princeton, Ky. \\
\hline Louisiana & Charlie Johnson & Louisiana State Univ. & Baton Rouge, La. \\
\hline Maryland & Chris Walsh & Univ. of Maryland & Keedysville, Md. \\
\hline Michigan & Dennis Fulbright & Michigan State Univ. & Jackson, Mich. \\
\hline Nebraska & Stan Matzke/Bill Gustafson & Univ. of Nebraska & Lincoln, Nebr. \\
\hline New York & Ian Merwin & Cornell University & Ithaca, N.Y. \\
\hline North Carolina & Mike Parker & N.C. State Univ. & Raleigh, N.C. \\
\hline Ohio & Brad Bergefurd & Ohio State Univ. & Piketon, Ohio \\
\hline Oregon $^{\mathrm{z}}$ & Kim Hummer & $\begin{array}{l}\text { USDA National Clonal Germplasm Repository, } \\
\text { Oregon State Univ. }\end{array}$ & Corvallis, Ore. \\
\hline South Carolina & Greg Reighard & Clemson Univ. & Clemson, S.C. \\
\hline
\end{tabular}

${ }^{\mathrm{z}}$ Outside pawpaw native range.

(West Chester, Pa.), and open-pollinated seed from some modern varieties. In 1993, the PPF and KSU embarked on a joint venture to test 10 commercially available pawpawvarieties and 18 of PPFs advanced selections from the Maryland orchards (Table 1). These advanced pawpaw selections were selected based on superior traits including fruit size and taste, high flesh-to-seed ratio, resistance to pests and diseases, and overall productivity on a year-to-year basis. From 1995 to 1999,12 universities or private cooperators established a PRVT (Pomper et al., 1999; Table 2). The objective of the PRVT plantings was to evaluate commercially available named pawpaw varieties and PPF's advanced selections within and outside of pawpaw's native range. In 1995, PRVT plantings were established in Kentucky (Princeton, Ky.), Louisiana, North Carolina, Oregon, and South Carolina. In 1998, a PRVT planting was established in Frankfort, Ky. In 1999, PRVT orchards were planted in Indiana, Iowa, Michigan, Maryland, Nebraska, New York, and Ohio. Here we report on the status of the pawpaw RVT plantings in Frankfort and Princeton, which were established in 1998 and 1995 , respectively.

\section{Materials and methods}

Plant material. Rootstock was propagated in greenhouses as described by Pomper et al., 2002a, 2002b). Seed for rootstock for both plantings was harvested from open-pollinated half-sibling trees in rows six and seven from the experimental pawpaw orchard at the Western Maryland Research and Education Center in Keedysville, Md. Buds of each of the varieties and advanced selections to be tested were donated by R. Neal Peterson and were chip budded onto actively growing 1 -year-old rootstock, 7 to $10 \mathrm{~mm}(0.3$ to 0.4 inch $)$ in diameter. Grafted trees were grown in the greenhouse over the summer. At both Kentucky PRVT sites, 8 replicate trees of each of the 28 grafted scion varieties (Table 2) were placed in a randomized complete block design with 8 complete blocks (block $=4$ rows $\times 7$ trees) at an in-row spacing of $2 \mathrm{~m}(6.6 \mathrm{ft})$ and between-row spacing of $5.5 \mathrm{~m}$ (18.04 $\mathrm{ft})$. Rows were placed in north-south orientation.

Frankfort PLANTING. Grafted trees were overwintered in a walk-in cooler until planting in late March 1998. A total of 224 grafted trees (eight trees of each selection), and 75 Kentucky seedlings serving as border row trees, were planted in a Lowell silt loam soil ( $\mathrm{pH}$ 6.9) at the KSU Research and Demonstration Farm in Frankfort. Trees were fertigated with Peters 20-20-20 (20N-8.7P-16.6K) water-soluble fertilizer (Scotts Co., Marysville, Ohio) once in May, June, July, and August each year for a total of $12.10 \mathrm{~kg} \cdot \mathrm{ha}^{-1}(10.8 \mathrm{lb} /$ acre $)$ of nitrogen $(\mathrm{N})$. Additional irrigation was provided as needed. Tree height was recorded early each spring from 1998 until 2001. Trunk diameter was determined in Apr. 2001. The number of fruit on each tree was counted on 4 July 2001 following the normal June drop period.

Princeton planting. A total of 224 grafted (eight trees of each selection), and 75 Kentucky seedling trees as border row trees, were planted in October 1995, in a Crider silt loam (pH 6.9) at the University of Kentucky Research and Education Center, Princeton. Trees were fertilized with $28.0 \mathrm{~kg} \cdot \mathrm{ha}^{-1}(25$ $\mathrm{lb} / \mathrm{acre}$ ) of N. For 2001, the number of fruit on each tree was counted on
3 July 2001. Average fruit weight was based on selections where 10 or more fruit were harvested and was determined on 27 and 30 Aug. 2001. The number of fruit produced by each selection was also determined at harvest in 2000. Average fruit weight for each selection was based on the weights of 10 or more fruit harvested on 25,29, and 30 Aug. 2000, and 1 and 13 Sept. 2000.

Statistical ANALYSIS. Data on trunk diameter, increase in tree height, and fruit weight by variety or advanced selection were subjected to GLM analysis of variance using the statistical program Costat (CoHort Software, Monterey, Calif.). Treatment means were separated based on the Student-Newman-Keuls separation of means, or independent $t$ tests when appropriate, at a significance level of $P<0.05$.

\section{Results}

Frankfort PLANTING. Of the 224 grafted trees that were planted in March $1998,95 \%$ of trees survived. Most of the trees that died were lost during the first summer after planting. The varieties Wilson and Taylor, and the advanced selection 2-10, had the poorest survival rate $(75 \%)$. All other varieties and advanced selections had survival rates of $88 \%$ or higher (Table 3 ).

Trunk diameter and tree growth (increase in tree height) varied significantly among varieties $(P<0.001$ for both variables). Based on trunk diameter measurements taken in 2001, most selections displayed excellent vigor, although some selections tended to have smaller-diameter trunks (e.g., 'Middletown', 11-5, 3-21, and 5-5). Based on height measurements taken from 1998 to 2001 , most selections also displayed excellent growth, though some selec- 
tions such as 3-21 and 9-47 did not exhibit as much growth as some of the more vigorous selections. There was a significant block effect on tree height for each variety $(P>0.038)$.

For trees that flowered during 1999 to 2001 , the main flush of flowers appeared in mid-April; some varieties had a more prolonged flowering period that extended into May. In 1999, there were 33 fruit on 14 trees. Selections with the most fruit were 'Middletown' (4 fruit), 'Mitchell' (4 fruit), 'Overleese' (4 fruit), 'Sunflower' ( 6 fruit), and 10-35 ( 5 fruit). As a result of a hard freeze on 9 Apr. 2000 , with temperatures dropping to $-2{ }^{\circ} \mathrm{C}\left(28.4^{\circ} \mathrm{F}\right)$, only 2 trees $(10-35)$ produced a total of 8 fruit. In 2001 , there were 74 fruit in the planting (Table 3 ). The variety PA-Golden had the best early fruit production as evidenced by the fact that 5 of 8 trees had fruit.
Princeton Planting. In the Princeton, Ky., planting, trees had an overall survival rate of $54 \%$ (Table 4 ). The only selection with eight remaining replicate trees was 10-35; selections with the poorest survival rate were 'Wells', 'Taylor', 5-5 and 'Middletown.' In 2000 , there were 528 fruit on 122 trees; selections with the greatest number of fruit (>30 fruit by selection) were: 'Sunflower', 'Wilson', 8-20, 8-58, and 11-13. In 2001, there were 652 total fruit on 122 trees; selections with the greatest number of fruit ( $>30$ fruit by selection) were: 'Middletown', 'NC-1', 'Sunflower', 'PA-Golden', 'Wilson', 1-23,8-20, and 9-58. Although tree diameter was not determined in the Princeton planting in 2001 before the growing season, trees were 3 years older, and thus larger than in the Frankfort planting. The average trunk diameter in July 2001 was $47 \pm 8 \mathrm{~mm}(1.9 \pm$ 0.3 inch), based on a sampling of the trunk diameter for 50 trees. The average trunk diameter before growth started in the Frankfort planting was $26 \pm 4$ $\mathrm{mm}(1.0 \pm 0.2$ inch $)$. Fruit fresh weight varied significantly among varieties $(P$ $<0.001$ ), with 1-7-1 showing the best overall fruit weight for both 2000 and 2001 , and 'Wilson' with a trend toward the smallest fruit weight in both years (Table 4).

\section{Discussion}

Pawpaw yields are notoriously low (Peterson 1991). Bartholomew (1962) reported obtaining $4 \mathrm{~kg}(8.8 \mathrm{lb})$ of fruit and Ourecky and Slate (1975) obtained 11.5 and $23 \mathrm{~kg}$ (25.35 and $50.7 \mathrm{lb})$ from superior pawpaw trees. For pawpaw trees in their seventh year (sixth leaf) in 2001 in Princeton, the bestyields

Table 3. Summary of tree growth and fruit production in 2001 for the Kentucky State University Pawpaw Regional Variety Trial (PRVT) in Frankfort, Ky.

\begin{tabular}{|c|c|c|c|c|c|}
\hline Selection $^{\mathrm{z}}$ & $\begin{array}{l}\text { Trunk } \\
\text { diam } \\
(\mathrm{mm})\end{array}$ & $\begin{array}{c}\text { Increase in } \\
\text { ht }(\mathrm{m})^{\mathrm{y}} \\
\text { from } 1999 \\
\text { to } 2001\end{array}$ & $\begin{array}{c}\text { Surviving } \\
\text { trees (\%) }\end{array}$ & $\begin{array}{l}\text { Surviving } \\
\text { trees with } \\
\text { fruit ( } \%)\end{array}$ & $\begin{array}{c}\text { Total } \\
\text { fruit (no. })^{\mathrm{x}}\end{array}$ \\
\hline PA-Golden & $36.7 \mathrm{a}^{\mathrm{w}}$ & $0.86 \mathrm{a}$ & 100 & 63 & 14 \\
\hline $10-35$ & $33.3 \mathrm{ab}$ & $0.76 \mathrm{abc}$ & 100 & 25 & 7 \\
\hline $8-20$ & $30.7 \mathrm{abc}$ & $0.60 \mathrm{abc}$ & 100 & 13 & 1 \\
\hline NC-1 & $30.3 \mathrm{abc}$ & $0.42 \mathrm{abc}$ & 100 & 0 & 0 \\
\hline $1-7-2$ & $29.6 \mathrm{abc}$ & $0.59 \mathrm{abc}$ & 100 & 0 & 0 \\
\hline Wilson & $29.5 \mathrm{abc}$ & $0.68 \mathrm{abc}$ & 75 & 17 & 2 \\
\hline $3-11$ & $28.8 \mathrm{abc}$ & $0.33 \mathrm{abc}$ & 88 & 0 & 0 \\
\hline Sunflower & $28.6 \mathrm{abc}$ & $0.80 \mathrm{ab}$ & 100 & 13 & 6 \\
\hline $1-68$ & $28.1 \mathrm{abc}$ & $0.58 \mathrm{abc}$ & 100 & 13 & 2 \\
\hline $9-58$ & $28.1 \mathrm{abc}$ & $0.32 \mathrm{abc}$ & 100 & 13 & 1 \\
\hline $7-90$ & $27.2 \mathrm{abcd}$ & $0.39 \mathrm{abc}$ & 100 & 0 & 0 \\
\hline $1-23$ & $27.1 \mathrm{abcd}$ & $0.28 \mathrm{abc}$ & 100 & 0 & 0 \\
\hline Taylor & $27.0 \mathrm{abcd}$ & $0.37 \mathrm{abc}$ & 75 & 17 & 2 \\
\hline $11-13$ & $26.8 \mathrm{abcd}$ & $0.86 \mathrm{a}$ & 100 & 13 & 5 \\
\hline $8-58$ & $26.0 \mathrm{abcd}$ & $0.23 \mathrm{bc}$ & 100 & 25 & 8 \\
\hline $9-47$ & $25.4 \mathrm{bcd}$ & $0.18 c$ & 100 & 25 & 4 \\
\hline Mitchell & $25.0 \mathrm{bcd}$ & $0.52 \mathrm{abc}$ & 100 & 0 & 0 \\
\hline $4-2$ & $24.7 \mathrm{bcd}$ & $0.49 \mathrm{abc}$ & 100 & 13 & 2 \\
\hline $1-7-1$ & $23.7 \mathrm{bcd}$ & $0.35 \mathrm{abc}$ & 88 & 0 & 0 \\
\hline Overleese & $23.6 \mathrm{bcd}$ & $0.35 \mathrm{abc}$ & 88 & 0 & 0 \\
\hline $2-54$ & $23.5 \mathrm{bcd}$ & $0.23 \mathrm{abc}$ & 100 & 0 & 0 \\
\hline Wells & $23.4 \mathrm{bcd}$ & $0.32 \mathrm{abc}$ & 88 & 29 & 11 \\
\hline $2-10$ & $22.6 \mathrm{bcd}$ & $0.55 \mathrm{abc}$ & 75 & 0 & 0 \\
\hline Taytwo & $22.0 \mathrm{bcd}$ & $0.38 \mathrm{abc}$ & 100 & 13 & 4 \\
\hline Middletown & $21.5 \mathrm{~cd}$ & $0.49 \mathrm{abc}$ & 100 & 25 & 2 \\
\hline $11-5$ & $20.5 \mathrm{~cd}$ & $0.35 \mathrm{abc}$ & 100 & 0 & 0 \\
\hline $3-21$ & $19.3 \mathrm{~cd}$ & $0.16 \mathrm{c}$ & 100 & 0 & 0 \\
\hline $5-5$ & $16.4 \mathrm{~d}$ & $0.32 \mathrm{abc}$ & 88 & 14 & 3 \\
\hline Avg $^{v}$ & $26.1 \pm 4.3$ & $0.46 \pm 0.20$ & $95 \pm 9$ & $12 \pm 14$ & $74^{\mathrm{u}}$ \\
\hline
\end{tabular}

${ }^{2}$ Trees were planted in Mar. 1998; selections ranked in order of increasing diameter.

yncrease in tree height from Apr. 1999 until Apr 2001; $1.00 \mathrm{~m}=3.281 \mathrm{ft}$.

yncrease in tree height from Apr. 1999 until Apr 2001; 1.00
xTotal number of fruit on remaining trees on 4 July 2001.

wStudent-Newman-Keuls separation of means at $P<0.05$.; $25.4 \mathrm{~mm}=1.0$ inch.

vAverage \pm SE.

"Sum. 
per tree were $4.4 \mathrm{~kg}$ per tree $(9.70 \mathrm{lb})$ for 'Sunflower', $2.3 \mathrm{~kg}$ per tree $(5.07$ lb) for $8-20$, and $2.2 \mathrm{~kg}$ per tree $(4.85$ lb) for 'PA-Golden'. Advanced selections from PPF failed to show greater yields than current named varieties in this study; however, some PPF selections may have higher quality fruit than named selections. Fruit quality of all PRVT selections will be examined in future studies. Also, these trees are still young and not in prime bearing years as yet. A spacing of $2.4 \mathrm{~m}(8 \mathrm{ft})$ between trees and $5.5 \mathrm{~m}(18 \mathrm{ft})$ between rows would result in a planting density of 729 trees/ha (295 trees/acre). Based on the yield data for 'Sunflower' in the Princeton planting in 2001, a tree could produce with 20 fruit per tree at a weight of $216 \mathrm{~g}(7.6 \mathrm{oz})$ per fruit. This is about $4.3 \mathrm{~kg}(9.48 \mathrm{lb})$ of fruit per tree or about $3,138 \mathrm{~kg} \cdot \mathrm{ha}^{-1}(2,800 \mathrm{lb} /$ acre $)$ at a $2.4 \times 5.5 \mathrm{~m}$ tree spacing. Pawpaw fruit prices during the 2001 growing season ranged between $\$ 4.41$ and $\$ 8.82$ per $\mathrm{kg}(\$ 2.00$ to $\$ 4.00$ per lb) at farmers markets in 2001 in the southeastern United States (R.N. Peterson and R. McIntosh, personal communication). Using the yield data above, the potential gross income from a pawpaw planting could be between $\$ 13,837$ to $\$ 27,675$ / ha $(\$ 5,600$ to $\$ 11,200 /$ acre $)$. If fruit prices remain high, pawpaw plantings could be profitable despite low yielding pawpaw selections.

The tropical Annonaceae relatives of the pawpaw, cherimoya (Annona cherimola), sweetsop or sugar apple $(A$. squamosa), soursop (A.muricata), and atemoya (A. squamosa $\times A$. cherimola $)$, also have low yields due to low rates of natural pollination (George et al., 1992; Pena et al., 1999; Peterson, 1991). In commercial plantings, these tropical pawpaw relatives are hand pollinated to increase yields (Pena et al., 1999; Peterson, 1991). Low rates $(<5 \%)$ of fruit set have also been noted in wild pawpaw patches (La grange and Tramer, 1985; Willson and Schemske, 1980). Pawpaw trees are usually found in the forest understory in hardwood forests; low light levels in the understory likely result in reduced photosynthate partitioning to fruit in the tree and low fruit set. However, pawpaws are also thought to require cross pollination (Willson and Schemske, 1980). Pawpaws in the wild often produce many root suckers that could potentially result in large clonal pawpaw patches. If a genetically different tree is not close enough to serve as a pollinizer, poor fruit set in patches is the likely result. Pollinator limitation could also result in low fruit set in the wild pawpaw patches (Willson and Schemske, 1980). Flies and beetles are thought to be the main pollinators of pawpaw,

Table 4. Summary of fruit production in 2001 for the Kentucky State University and University of Kentucky Pawpaw Regional Variety Trial (PRVT) in Princeton, Ky.

\begin{tabular}{|c|c|c|c|c|c|c|}
\hline Selection $^{z}$ & $\begin{array}{c}\text { Total } \\
\text { fruit (no.) } \\
\text { in } 2000^{y}\end{array}$ & $\begin{array}{c}\text { Avg fruit } \\
\text { wt (g) } \\
\text { in } 2000^{x}\end{array}$ & $\begin{array}{c}\text { Total } \\
\text { fruit (no.) } \\
\text { in } 2001^{\mathrm{y}}\end{array}$ & $\begin{array}{l}\text { Avg fruit } \\
\text { wt (g) } \\
\text { in } 2001^{x}\end{array}$ & $\begin{array}{c}\text { Surviving } \\
\text { trees (\%) } \\
\text { with fruit } \\
\text { in } 2001^{w}\end{array}$ & $\begin{array}{c}\text { Surviving } \\
\text { trees }(\%) \\
\text { in } 2001 \\
\end{array}$ \\
\hline Sunflower & 89 & $159 b^{v}$ & 82 & $216 a$ & 80 & 63 \\
\hline PA-Golden & 18 & $125 \mathrm{bcd}$ & 69 & $128 \mathrm{~cd}$ & 67 & 75 \\
\hline Wilson & 73 & $86 \mathrm{~d}$ & 63 & $104 \mathrm{~d}$ & 83 & 75 \\
\hline $1-23$ & 17 & $152 \mathrm{bc}$ & 46 & $149 \mathrm{bcd}$ & 100 & 50 \\
\hline $8-20$ & 62 & $145 \mathrm{bc}$ & 45 & $212 \mathrm{ab}$ & 80 & 63 \\
\hline Middletown & 17 & $107 \mathrm{~cd}$ & 37 & --- & 100 & 25 \\
\hline NC-1 & 16 & $177 \mathrm{ab}$ & 36 & $215 \mathrm{a}$ & 67 & 75 \\
\hline $9-58$ & 1 & --- & 31 & $175 \mathrm{abcd}$ & 60 & 63 \\
\hline $2-10$ & 0 & --- & 28 & --- & 33 & 75 \\
\hline Wells & 17 & $70 \mathrm{~d}$ & 27 & $135 \mathrm{bcd}$ & 100 & 13 \\
\hline $8-58$ & 70 & $129 \mathrm{bc}$ & 23 & $157 \mathrm{abcd}$ & 40 & 63 \\
\hline $10-35$ & 11 & --- & 22 & $216 \mathrm{a}$ & 50 & 100 \\
\hline $1-7-2$ & 0 & --- & 19 & --- & 75 & 50 \\
\hline $11-13$ & 48 & $158 \mathrm{~b}$ & 15 & 199 abc & 50 & 50 \\
\hline Mitchell & 11 & --- & 14 & --- & 33 & 75 \\
\hline Taylor & 0 & --- & 13 & --- & 100 & 25 \\
\hline $5-5$ & 21 & $184 \mathrm{ab}$ & 13 & --- & 50 & 25 \\
\hline $11-5$ & 4 & --- & 12 & --- & 40 & 63 \\
\hline $1-68$ & 0 & --- & 12 & $95 \mathrm{~d}$ & 25 & 50 \\
\hline $3-11$ & 2 & --- & 10 & --- & 50 & 50 \\
\hline $9-47$ & 14 & $127 \mathrm{bc}$ & 10 & $157 \mathrm{abcd}$ & 67 & 38 \\
\hline Taytwo & 21 & $116 \mathrm{~cd}$ & 5 & --- & 33 & 38 \\
\hline $1-7-1$ & 10 & $208 \mathrm{a}$ & 11 & $244 a$ & 67 & 38 \\
\hline $3-21$ & 0 & --- & 3 & --- & 40 & 63 \\
\hline $4-2$ & 1 & --- & 3 & --- & 67 & 38 \\
\hline $7-90$ & 0 & --- & 3 & --- & 20 & 63 \\
\hline $2-54$ & 5 & --- & 0 & --- & 0 & 63 \\
\hline Overleese & 0 & --- & 0 & --- & 0 & 63 \\
\hline Total & 528 & --- & 652 & --- & $52 \pm 20$ & $54 \pm 28$ \\
\hline
\end{tabular}

${ }^{2}$ Trees were planted in October 1995; trees ranked in decreasing number of total fruit produced by variety

Total number of fruit on remaining trees on 3 July 2001.

${ }^{x}$ Average fruit weight based on 10 or more fruit harvested on $7,12,13$ Sept. $2001 ; 100 \mathrm{~g}=3.5 \mathrm{oz}$

"Average $\pm \mathrm{SE}$.

vStudent-Newman-Keuls separation of means at $P<0.05$ 
and many of these insects have been observed each spring in the pawpaw orchards at KSU. Low pollinator activity is usually observed on cool cloudy spring days (unpublished). If cool and cloudy weather conditions coincide with the main bloom period, pawpaw fruit set may be low. Since the pawpaw flowers are strongly protogynous (Willson and Schemske, 1980), lack of pollen availability from other pawpaw genotypes could also limit pollination. Pawpaw growers report that placing carrion in buckets in pawpaw trees has resulted in improvements in fruit set (L. Sibley, personal communication), thus supporting the theory that pawpaw flowers may be pollinated by carrion flies. Fruit set has been high in the past in the KSU orchards; fruit set was $25 \% \pm$ $10 \%$ in 1998 for 10 seedlings that were in their ninth year (eighth leaf) in the KSU pawpaw orchards. Many pawpaw genotypes are in close proximity at the KSU farm. Flies are usually abundant in the KSU orchards and a herd of cattle is maintained in a field less than 152.4 $\mathrm{m}(500 \mathrm{ft})$ from the pawpaw trees. Fruit set was not examined in the PRVT orchards. It has been suggested by some hobbyists that the variety Sunflower may be self-fruitful; however this has not been experimentally documented. Interestingly, 'Sunflower' did produce the greatest number of fruit per tree in this study, raising the possibility that self-fruitfulness in 'Sunflower' could have resulted in greater fruit set in this selection. Pollinizer relationships between pawpaw varieties and PPF advanced selections have not been examined. Hand pollination of pawpaw would be expensive and time consuming; however, this could also lead to greater yields in the PRVT selections being tested.

Pawpaws have few disease problems. Pawpaw leaves can exhibit leaf spot, principally Mycocentrospora aiminae (Farr et al., 1989; Peterson, 1991) and some trees in the PRVT planting in Frankfort have exhibited signs of this foliar disease. The pawpaw peduncle borer (Talponia plummeriana) is a small moth larva [about $5 \mathrm{~mm}$ (0.2 inch) long] that burrows into the fleshy tissues of the flower causing the flower to wither and drop (Heinrich, 1926; MacKay, 1959; Peterson, 1991). Signs of the pawpaw peduncle borer have been observed in pawpaw orchards in at the University of Maryland Experiment Station at Wye, Md. (R.N. Peterson, personal communication), but not in the PRVT planting in Frankfort. The zebra swallowtail butterfly (Eurytides marcellus), whose larvae feed exclusively on young pawpaw foliage, will damage leaves, but this damage has been negligible at the PRVT plantings. In 2000, six trees in the PRVT orchard at Frankfort were damaged severely by male deer rubbing their antlers on trees in winter. Deer will not generally eat the leaves or twigs, but they will eat fruit that has dropped on the ground in the KSU orchards. Finally, japanese beetles (Popillia japonica) damaged many young leaves on pawpaw trees in the Frankfort PRVT orchard in July 2001.

In conclusion, the selections 'Sunflower', 'PA-Golden', 'NC-1', 'Wilson', $1-23,8-20$, and $9-58$ showed the best fruit production and survival rates $(>63 \%)$ in 2001 . Based on limited data collected so far in the Kentucky trials, 'PA-Golden' and 'Sunflower' have at least performed well in the two locations and other varieties and PPF selections show promise. Orchard performance will continue to be examined at each site in terms of pests, growth, flowering, yield, year-to-year consistency, and fruit characteristics in the coming years at the PRVT plantings.

\section{Literature Cited}

Bartholomew, E.A.1962. Possibilities of the pawpaw. N. Nut Growers Assn. Annu. Rpt. 53:71-74

Darrow, G.M. 1975. Minor temperate fruits, p. 276-277. In: J. Janick and J.N. Moore (eds.). Advances in fruit breeding. Purdue Univ. Press, West Lafayette, Ind.

Farr, D.F., G.F. Bills, G.P. Chamuris, and A.Y. Rossmoan. 1989. Fungi on plants and plant products in the United States. APS Press, St. Paul, Minn

George, A.P., R.J. Nissen, and J.A. Campbell. 1992. Pollination and selection in Annona species (cherimoya, atemoya, and sugar apple). Acta Hort. 321:178-185

Heinrich, C. 1926. Revision of the North American moths of the subfamilies Laspeyresiinae and Olethreutinae. U.S. Natl. Museum Bul. 132.

Huang, H., D.R. Layne, and R.N. Peterson. 1997. Using isozyme polymorphisms for identifying and assessing genetic variation in cultivated pawpaw [Asiminatriloba (L.) Dunal.]. J.Amer.Soc. Hort. Sci. 122:504-511.

Huang, H., D.R. Layne, and D.E. Riemenschneider. 1998. Genetic diversity and geographic differentiation in pawpaw [Asimina triloba (L.) Dunal.] populations from nine states as revealed by allozyme analysis. J. Amer. Soc. Hort. Sci. 123:635-641.

Huang, H., D.R. Layne, and T.L. Kubisiak. 2000. RAPD Inheritance and diversity in pawpaw [Asimina triloba (L.) Dunal.]. J. Amer. Soc. Hort. Sci. 125:454-459.
Huang, H., D.R. Layne, and T.L. Kubisiak. 2003. Molecular characterization of cultivated pawpaw [Asimina triloba (L.) Dunal.] using RAPD markers. J. Amer. Soc. Hort. Sci. 128:85-93.

Jones, S.C, R.N. Peterson, T. Turner, K.W. Pomper, and D.R. Layne. 1998. Pawpaw planting guide: Cultivars and nursery sources. Ky. State Univ. Pawpaw Ext. Bul. 002.

Kral, R. 1960. A revision of Asimina and Deeringothamnus (Annonaceae). Brittonia 12: 233-278.

Lagrange, R.L. and E.J. Tramer. 1985. Geographic variation in size and reproductive success in the paw paw (Asimina triloba). Ohio J. Sci. 85:40-45.

Layne, D.R. 1996. The pawpaw [Asimina triloba (L.) Dunal.]: A new fruit crop for Kentucky and the United States. HortScience 31:777-784.

MacKay, J.W. 1959. Variation in papaw. N. Nut Growers Assn. Annu. Rpt. 66:53-55.

McGrath, M.J. and C. Karahadian. 1994. Evaluation of physical, chemical, and sensory properties of pawpaw fruit (Asimina triloba) as indicators of ripeness. J. Agr. Food Chem. 42:968-974.

Ourecky, D.K. and G.L. Slate. 1975. Evaluation system for papaw fruit. N. Nut Growers Assn. Annu. Rpt. 65:57-58

Pena, J.E.,A. Castineiras, R. Bartelt, and R. Duncan. 1999. Effect of pheromone for sap beetles (Coleoptera: Nitidulidae) on Annona spp. fruit set. Fla. Entomol. 82:475-480.

Peterson, R.N. 1986. Research on the pawpaw (Asimina triloba) at the University of Maryland. N. Nut Growers Assn. Annu. Rpt. 77:73-78.

Peterson, R.N. 1991. Pawpaw (Asimina). Acta Hort. 290:567-600.

Pomper, K.W., D.R. Layne, and R.N. Peterson. 1999. The Pawpaw Regional Variety Trial, $p$ 353-357. In: J. Janick (ed.). Perspectives on new crops and new uses. ASHS Press, Alex., Va.

Pomper, K.W., D.R. Layne, and S.C. Jones. 2002a. Incident irradiance and cupric hydroxide container treatment effects on early growth and development of container-grown pawpaw seedlings. J. Amer. Soc. Hort. Sci. 127:13-19.

Pomper, K.W., D.R. Layne, S.C. Jones, and M.G. Kwantes. 2002b. Growth enhancement of container-grown pawpaw seedlings as influenced by media type, root-zone temperature, and fertilization regime. HortScience 37:329-333.

Pomper, K.W., S.B. Crabtree, S.P. Brown, S.C. Jones, T.M. Bonney, and D.R. Layne. 2003. Assessment of genetic diversity of pawpaw varieties with inter-simple sequence repeat markers. J. Amer. Soc. Hort. Sci. 128(4):521-525.

Popenoe, W. (ed.). 1916. Where are the best papaws? J. Hered. 7:291-296.

Popenoe, W. (ed.). 1917. The best papaws. J. Hered. 8:21-33.

Sargent, C.S. 1890. Silva of North America Houghton Mifflin, New York.

Shiota, H. 1991. Volitile componets of pawpaw fruit (Asimina triloba Dunal.). J. Agr. Food Chem. 39:1631-1635.

Willson, M.F. and D.W. Schemske. 1980. Pollinator limitation, fruit production, and floral display in pawpaw (Asimina triloba). Bul. Torrey Bot. Club 107:401-408

Zimmerman, G.A. 1941. Hybrids of the american pawpaw. J. Hered. 32:83-91. 